\title{
Designing of Curriculum Aspects of Pharmacy Undergraduate Course in Respect of Graduate Employability
}

\author{
Shivaji P.Gawade ${ }^{*}$, Nitin P.Sonaje ${ }^{2}$ \\ ${ }^{1}$ Sahyadri College of Pharmacy, Methwade, Sangola, Dist.Solapur-413307, Maharashtra, INDIA. \\ ${ }^{2}$ Centre of distance Education, Shivaji University, Kolhapur, Maharashtra, INDIA.
}

\begin{abstract}
Objectives: Objective of the present research work was to enhance graduate employability based on the needs of pharmaceutical industries, to evaluate present undergraduate curriculum and to redefine it by conducting survey of industrial, academic professionals other than pharmacy and clinical professionals. Materials and Methods: Questionnaire survey design of 15 multiple choice questions, was prepared to generate opinions of four types of professionals, industrial, academic, clinical and professionals other than pharmacy working in the pharmaceutical industry. Sampling was performed directly by face to face interviews with industrial, academic staffs, pharmacy post graduates and indirectly by electronic mail service. Results and Discussion: The total seventy eight samples from human subjects of four categories were tabulated category wise and alphabet (a), (b), (c) and (d) preferences from multiple choice questions. The results were statistically analysed for Standard deviation (S.D.), Standard Error Mean (SEM), (S.D.) $)^{2}$ i.e. Variance (V) and $F$ calculated value as a ratio of Variances. Conclusion: It is emphacized that there is a need to change existing curriculum, to affiliate pharmacy curriculum to health Science University, to confer degree as B. Pharm. (Pharmaceutical Industry) and B. Pharm. (Clinical Industry) and adequate industrial exposure to teacher to train students and their participation in the teacher training course to train students on current industrial and technological development to bridge their gap between college laboratory to the industrial practice.
\end{abstract}

Key words: Graduate employability, Questionnaire survey design, Samples from human subjects, F-statistics.

\section{INTRODUCTION}

The graduate employability in India is a global concern as increasing number of graduates produced by higher education in pharmaceutical field each year. Graduate should acquire both theoretical and practical skills in order to become work deliverable and to perform well at work. In India, there is mushroom growth of pharmacy education. In early 1980's there were 11 universities and 26 colleges offering pharmacy education at Bachelor and Master's level. In 2007, there were 854 institutions that admitted about 52000 students for B. Pharm. degree course. In 2010-2011 as per the AICTE, there were 1102 degree institutions that admitted 103867 students for degree pharmacy course. In the context of current scenario of lack of exposure to the latest development in pharma industry, intellectual property right, industry based regulatory needs, unawareness about NDA pipe line and development in new therapeutics, it is urged to inculcate awareness to update existing degree pharmacy curriculum. Keeping in view of requirements and expectations of industry. Australian Chamber of commerce and industry and business council of Australia $(\mathrm{ACCI} / \mathrm{BCA})^{1}$ reported identifi-
Submission Date : 27-05-2016 Revision Date : :31-08-2016 Accepted Date : 28-10-2016

DOI: 10.5530/ijper.51.4.78

Correspondence:

Prof (Dr) Shivaji $P$. Gawade,

Principal, Sahyadri College of Pharmacy, Methwade,

Tal. Sangola, Dist.

Solapur-413 307, Maharashtra, INDIA.

Mobile no. 9096227261

E-mail: Gneskw@gmail.com

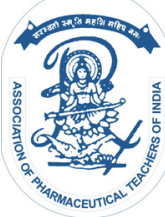

www.ijper.org 
cation of eight skills for employability. These skills are communication, team work, problem solving, initiative and enterprise, planning and organising, self management, learning and technology. Number of intervention methods were taken by individuals to enhance graduate employability and marketability. It includes bridging gap program, apprentice ship program, entrepreneurship program to able to optimize and enhance strength and capability of graduates before completion of graduate course in order to achieve the excellence in performance at work place. Brown and Hesketh $^{2}$ reported that inequalities exist among the graduates in their labour market outcomes. It was observed that many of the graduates are not utilizing their knowledge and skills from their higher education and that "positional" differences exist between graduates on the basis of social class, gender and ethnic status. Guvinder and Sharma ${ }^{3}$ emphasized on seven principal employability factors namely English language proficiency, literacy skills, Information Communication Technology (ICT) skills, problem solving and adaptability skills, time management skills, leadership skills and communication skills. Pande and co-workers ${ }^{4}$ reported that about $85 \%$ of the $1^{\text {st }}$ year B.Pharm. surveyed, inclined to take up career orientation programme which will help while deciding the career after graduation whereas about $90 \%$ of the student surveyed, are very much opt to know the essential knowledge such as communication skills, personality development, attitude towards job. It was concluded that orientation program will save their energy and time and also improve opportunities to get the job they desire. Malaysian online employability test kit (MASKIT) was development for graduates to overcome the lacunae of non availability of several survival skills at work. The MASKIT include prototype design to identify and to bench mark the graduate competency and performance of different soft skills. ${ }^{5}$ National graduate employment blue print (2012-2017) defined employment as the potential to secure a job at a work place where as employability is the potential to secure, maintain and grow in a particular job at a work place. ${ }^{6}$ Desale ${ }^{7}$ opined role of knowledge and attention towards curriculum development in creation of knowledge to increase employability of the students. It is planned for empirical and explosive interviews with professionals and educators to generate data by verbal and non-verbal communication using questionnaire survey and to design curriculum by effective liaison, networking, didactic approach and co-operation between, academia, industry and hospitals to reinforce positive attitude and overall development to cope up with competitive and ever changing demand of pharmacy profession.

\section{MATERIALS AND METHODS}

\section{Questionnaire survey design}

Questionnaire survey of 15 multiple choice questions based on the undergraduate pharmacy curriculum, aspects of curriculum regulation, existing state of art and improvements anticipated in the curriculum by raising queries in the form of MCQs and inviting concerned human subjects as a sample for preferential opinions. Table 1, depicted questionnaire survey design of 15 MCQs with four closely related options.

\section{Collection of Samples from Human Subjects}

Samples of human subjects were collected by (i) Direct face to face interview and (ii) Indirect by electronic mail. Sampling from Industrial Pharmacy Professionals was conducted by direct interview with industrial professionals employed in the three pharmaceutical medium sized companies in MIDC Satara and by communication using electronic media of e.mail service. Sampling from Academic Pharmacy Professionals was conducted from two academic pharmacy institutions engaged in teaching profession affiliated to Solapur University. Questionnaire sheets were also distributed to the delegates from pharmacy profession clinical, industrial and academic professionals attended meeting of Maharashtra Community Pharmacist Association held at Pune. Sampling from industrial or academic professionals other than pharmacy was conducted by distributing questionnaire sheets and also by electronic mail communication service. Sampling from Clinical Professionals was conducted by communication electronically by e.mail. service.

Table 2, summarised different category of respondents participated in the questionnaire survey.

\section{Statistical Analysis}

The data tabulated from Questionnaire survey sheet was transformed from alphabet coding to the number of times the respondents preferred the code. The data of three categories was analysed for sum, mean, standard deviation (S.D.), Standard Error Mean (SEM), Variance (V) i.e. Standard Deviation Square (S.D.) $)^{2}$ and a ratio of Variances as calculated $F$ value and interpretation based on tabulated $\mathrm{F}$ value at 0.05 level of significance. The results of statistical analysis of the data were summarized in Table 3-A (i) (ii). Table-3-B-(i), (ii) and Table 3-C-(i), (ii).

\section{DATA ANALYSIS AND INTERPRETATION}

Sample frequencies of each category of professionals PIP, PAP and AIOP responding to the 15 questions from four multiple choices were coded alphabetically 


\begin{tabular}{|c|c|c|}
\hline $\begin{array}{l}\text { Question } \\
\text { No }\end{array}$ & $\begin{array}{l}\text { Alphabet code }(a) /(b) / \\
(\text { c }) /(d)\end{array}$ & Answer \\
\hline \multirow[t]{5}{*}{01} & & What is your professional involvement? \\
\hline & (a) & Clinical professional \\
\hline & (b) & Pharmacy Academic professional \\
\hline & (c) & Pharma.Industry professional \\
\hline & (d) & $\begin{array}{l}\text { Senior academic/industry professional other } \\
\text { than pharmacy }\end{array}$ \\
\hline \multirow[t]{5}{*}{02} & & What is your perception about the existing pharmacy curriculum? \\
\hline & (a) & Need not be changed \\
\hline & (b) & Need to be changed drastically \\
\hline & (c) & Need to be changed partially \\
\hline & (d) & Need to be changed completely \\
\hline \multirow[t]{5}{*}{03} & & What is your opinion about the affiliation of Pharmacy undergraduate program? \\
\hline & (a) & Technological University \\
\hline & (b) & Health Science University \\
\hline & (c) & Allied Health Science in Medical University \\
\hline & (d) & In Faculty of Technology affiliated to the University \\
\hline \multirow[t]{5}{*}{04} & & $\begin{array}{l}\text { Do you think that prospective future pharmacist with qualification B.Pharm } \\
\text { (Industrial) or B.Pharm.(Clinical) as well defined streams. }\end{array}$ \\
\hline & (a) & $\begin{array}{l}\text { The course work for students from maths /Biology is compensated by remedial biology / } \\
\text { maths subjects. Two streams at degree level will foster to mould their professional life. }\end{array}$ \\
\hline & (b) & By making two streams, interest and abilities of students will be preserved. \\
\hline & (c) & $\begin{array}{l}\text { Students will have choice to choose the stream to supersede proper utilization of lecture } \\
\text { hours to develop their career. }\end{array}$ \\
\hline & (d) & $\begin{array}{l}\text { Sub-branches at undergraduate level will provide opportunity to shape their career after } \\
\text { graduation for choosing the employment and further studies. }\end{array}$ \\
\hline \multirow[t]{5}{*}{05} & & What is your suggestion about the structure of existing pharmacy curriculum? \\
\hline & (a) & $\begin{array}{l}\text { Needs to be revised thoroughly by replacing the existing modern methodology practiced } \\
\text { in the industry. }\end{array}$ \\
\hline & (b) & It should have uniformity at national level such as model AICTE syllabus. \\
\hline & (c) & $\begin{array}{l}\text { It should get provision for students to select subjects of their choice to develop career as } \\
\text { B.Pharm. (Industrial) or (Clinical) from } 2^{\text {nd }} \text { Year B.Pharm course. }\end{array}$ \\
\hline & (d) & $\begin{array}{l}\text { It should have adequate provision of soft skill development, industrial interactions, } \\
\text { assignments and training within the syllabus. }\end{array}$ \\
\hline \multirow[t]{5}{*}{06} & & $\begin{array}{l}\text { Which area in your opinion, pharmacy graduate should have adequate professional } \\
\text { training for the Job? }\end{array}$ \\
\hline & (a) & Regulatory and quality management \\
\hline & (b) & Modern analytical techniques \\
\hline & (c) & Clinical research \\
\hline & (d) & Novel drug delivery system \\
\hline \multirow[t]{5}{*}{07} & & $\begin{array}{l}\text { What measures needs to be taken to make pharmacy students aware of the latest } \\
\text { Pharma.industrial /clinical development? }\end{array}$ \\
\hline & (a) & Guest lectures by Industrial /clinical experts \\
\hline & (b) & Workshops and seminars on recent industrial development \\
\hline & (c) & Training to teaching faculty on technological advancement in the industry \\
\hline & (d) & Educational/informative industrial visits of students. \\
\hline 08 & & $\begin{array}{l}\text { What is your advice about the soft skill lecture course in the under graduate degree } \\
\text { pharmacy curriculum? }\end{array}$ \\
\hline
\end{tabular}




\begin{tabular}{|c|c|c|}
\hline & (a) & To be covered in two semesters I and II of the $1^{\text {st }}$ Year B.Pharm. \\
\hline & (b) & By arranging regular visiting lectures during the graduation. \\
\hline & (c) & By arrangement of workshop, seminars and guest lectures on soft skill development. \\
\hline & (d) & To be covered in two semesters I and VIII of $1^{\text {st }}$ and $4^{\text {th }}$ Year B.Pharm. \\
\hline \multirow[t]{5}{*}{09} & & What are student services from your opinion to foster student professionalism? \\
\hline & (a) & Guest lectures by industrial professionals. \\
\hline & (b) & Industrial visits for attending seminars \\
\hline & (c) & Regular course work on soft skills development \\
\hline & (d) & Training to teachers on modern teaching methodology and pedagogy. \\
\hline \multirow[t]{5}{*}{10} & & $\begin{array}{c}\text { What advice you have for the teachers to develop job oriented professionalism in the } \\
\text { curriculum? }\end{array}$ \\
\hline & (a) & To avail training to students on modern technology and industrial practice. \\
\hline & (b) & $\begin{array}{l}\text { To attend teacher training course on teaching methodology and pedagogy of industrial } \\
\text { concern. }\end{array}$ \\
\hline & (c) & $\begin{array}{c}\text { To participate in the workshop/seminars for teachers on curriculum development and } \\
\text { modern teaching methodology. }\end{array}$ \\
\hline & (d) & To acquaint student with latest development by regular industrial visits. \\
\hline \multirow[t]{5}{*}{11} & & $\begin{array}{c}\text { Which area pharmacy graduate should have training for the job in clinical / Health } \\
\text { care industry? }\end{array}$ \\
\hline & (a) & To Acquaint with Phase 0 to Phase IV clinical trial and GCP guidelines. \\
\hline & (b) & Evaluation of toxicity, BA/BE and PMS studies. \\
\hline & (c) & Monitoring,reporting, maintenance of data and documentation \\
\hline & (d) & Preparation, execution, designing protocol of CR and ICF. \\
\hline \multirow[t]{5}{*}{12} & & Which soft skill development, student should have to cultivate professionalism? \\
\hline & (a) & Leadership skill \\
\hline & (b) & Behavioural trait (attitude, motivation and time management \\
\hline & (c) & Team spirit \\
\hline & (d) & Communication skill \\
\hline \multirow[t]{5}{*}{13} & & $\begin{array}{c}\text { What type of training pharmacy graduate should have for job opportunities as a } \\
\text { clinical industry professional ? }\end{array}$ \\
\hline & (a) & Clinical trial data collection and management \\
\hline & (b) & New drug development \\
\hline & (c) & Regulatory affairs \\
\hline & (d) & To conduct and co-ordinate clinical trial \\
\hline \multirow[t]{5}{*}{14} & & Pharmacy student should get acquainted in the areas of research and development. \\
\hline & (a) & Development of methods for NCE, NDA and ANDA. \\
\hline & (b) & Analytical methods for scale up techniques. \\
\hline & (c) & Validation methods for product quality \\
\hline & (d) & Calibration and maintenance of lab. Instrument with GMP. \\
\hline \multirow[t]{5}{*}{15} & & Evaluation methods of good pharmacy education practice. \\
\hline & (a) & Report writing after industrial project work. \\
\hline & (b) & Objective test after guest lecture/seminar/workshop \\
\hline & (c) & Report on project in community pharmacy/Hospital. \\
\hline & (d) & Preparation of working model or fabrication \\
\hline
\end{tabular}




\begin{tabular}{|c|c|c|}
\hline \multicolumn{3}{|c|}{ Table 2: Respondents participated in the Question- } \\
naire Survey Design \\
\hline $\mathbf{0 1}$ & $\begin{array}{c}\text { Shample type (Human Subjects) } \\
\text { Phomber of Industry Professionals } \\
\text { (PIP) }\end{array}$ & $\begin{array}{c}\text { Number } \\
\text { respondents }\end{array}$ \\
\hline $\mathbf{0 2}$ & $\begin{array}{c}\text { Pharmacy Academic Professionals } \\
\text { (PAP) }\end{array}$ & 24 \\
\hline $\mathbf{0 3}$ & $\begin{array}{c}\text { Senior academic /industry } \\
\text { professional other than pharmacy } \\
\text { (AlOP) }\end{array}$ & 13 \\
\hline $\mathbf{0 4}$ & Clinical professionals (CP) & 02 \\
\hline & \begin{tabular}{c} 
Total Samples \\
\hline
\end{tabular} \\
\hline
\end{tabular}

\section{Table 3 : A (i) - Statistical analysis of sample data of} PIP $(n=24)$

\begin{tabular}{|c|c|c|c|c|}
\hline Q 2 - Q15 & a & b & c & d \\
\hline Sum & 105 & 72 & 72 & 60 \\
\hline Mean & 8.077 & 5.538 & 5.538 & 4.615 \\
\hline S,D, & 3.904 & 2.634 & 4.115 & 2.755 \\
\hline SEM & 1.083 & 0.7304 & 1.141 & 0.764 \\
\hline $\begin{array}{c}\text { V=Variance } \\
\text { (S.D.)2 }\end{array}$ & $\begin{array}{c}15.2412 \\
\text { (V2) }\end{array}$ & $\begin{array}{c}6.9378 \\
\text { (V4) }\end{array}$ & $\begin{array}{c}16.9332 \\
\text { (V1) }\end{array}$ & $\begin{array}{c}7.5900 \\
\text { (V3) }\end{array}$ \\
\hline
\end{tabular}

\section{Table 3: A (ii) F distribution of variance from sample} data of PIP

\begin{tabular}{|c|c|c|c|c|}
\hline Sr.No & $\begin{array}{c}\text { Variance } \\
\text { ratio }\end{array}$ & $\begin{array}{c}\mathbf{F} \text { cal } \\
(\mathbf{n}-1)\end{array}$ & $\mathbf{D f}=\mathbf{( n - 1 )}$ & $\begin{array}{c}\mathbf{F} \text { tab } \\
\text { Critical } \\
\text { value }\end{array}$ \\
\hline 01 & $\mathrm{~V} 1 / \mathrm{V} 2$ & 1.111 & 23 & 2.33 \\
\hline 02 & $\mathrm{~V} 1 / \mathrm{V} 3$ & 2.231 & 23 & 2.33 \\
\hline 03 & $\mathrm{~V} 1 / \mathrm{V} 4$ & 2.441 & 23 & 2.33 \\
\hline
\end{tabular}

DECISION : Calculated F-value for degrees of freedom $\mathrm{dF}_{1}, \mathrm{dF}_{2}$ and $\mathrm{dF}_{3}=23$ is less than the tabulated $F$ value for $V_{1} / V_{2}$ and $V_{1} / V_{3}$, the null hypothesis is accepted at 0.05 level. For $V_{1} / V_{4}$ tabulated $F$ value is less than calculated value, the null hypothesis is rejected and alternative hypothesis is accepted at 0.05 levels.

\begin{tabular}{|c|c|c|c|c|}
\hline & (a) & (b) & (c) & (d) \\
\hline Sum & 95 & 158 & 146 & 100 \\
\hline Mean & 6.786 & 11.29 & 10.43 & 7.143 \\
\hline S.D. & 2.966 & 3.811 & 5.571 & 4.074 \\
\hline SEM & 0.7977 & 1.019 & 1.489 & 1.089 \\
\hline $\begin{array}{c}\text { Variance } \\
(V)=(S . D) 2\end{array}$ & $\begin{array}{c}0.6363 \\
(V 4)\end{array}$ & $\begin{array}{c}14.523 \\
\text { (V3) }\end{array}$ & $\begin{array}{c}31.036 \\
\text { (V1) }\end{array}$ & $\begin{array}{c}16.597 \\
(\mathrm{~V} 2)\end{array}$ \\
\hline
\end{tabular}

\begin{tabular}{|c|c|c|c|c|}
\hline Sr.No & $\begin{array}{l}\text { Variance } \\
\text { ratio (F) }\end{array}$ & $F$ cal $(n-1)$ & $\begin{array}{l}\text { Degree of } \\
\text { freedom } \\
\text { (dF) }\end{array}$ & $\begin{array}{c}\mathrm{F} \text { tab } \\
\text { Critical } \\
\text { value }\end{array}$ \\
\hline 01 & $\mathrm{~V} 1 / \mathrm{V} 2(\mathrm{~F} 1)$ & 1.8699 & 38 & $1.88-1.93$ \\
\hline 02 & $\mathrm{~V} 1 / \mathrm{V} 3(\mathrm{~F} 2)$ & 2.1370 & 38 & $1.88-1.93$ \\
\hline 03 & V1/V4 (F3) & 48.770 & 38 & $1.88-1.93$ \\
\hline
\end{tabular}

DECISION: Calculated F-value for degrees of freedom $\mathrm{dF}_{1}, \mathrm{dF}_{2}$ and $\mathrm{dF}_{3}=38$ is less than the tabulated $F$ value, the null hypothesis is accepted for the $F$ cal. ( $\left.F_{1}\right)$ at 0.05 level. $F_{2}$ and $F_{3}$ cal. values are lesser than $F_{2}$ and $F_{3}$ tabulated indicating that alternative hypothesis is accepted at 0.05 level.

\begin{tabular}{|c|c|c|c|c|}
\hline Q2-Q15 & (a) & (b) & (c) & (d) \\
\hline Sum & 21 & 50 & 57 & 45 \\
\hline Mean & 1.5 & 3.571 & 4.047 & 3.214 \\
\hline S.D. & 1.454 & 1.950 & 2.093 & 1.718 \\
\hline SEM & 0.3387 & 0.5211 & 0.5593 & 0.4591 \\
\hline$V=(S . D) 2$ & $\begin{array}{c}2.114 \\
\text { (V4) }\end{array}$ & $\begin{array}{c}3.803 \\
(\mathrm{~V} 2)\end{array}$ & $\begin{array}{c}4.381 \\
(\mathrm{~V} 1)\end{array}$ & $2.9515(\mathrm{~V} 3)$ \\
\hline
\end{tabular}

\begin{tabular}{|c|c|c|c|c|}
\hline Sr.No & $\begin{array}{l}\text { Variance } \\
\text { ratio (F) }\end{array}$ & F cal $(n-1)$ & $\begin{array}{l}\text { Degree of } \\
\text { freedom } \\
\text { (dF) }\end{array}$ & $\begin{array}{c}\mathrm{F} \text { tab } \\
\text { Critical } \\
\text { value }\end{array}$ \\
\hline 01 & $\mathrm{~V} 1 / \mathrm{V} 2(\mathrm{~F} 1)$ & 1.1592 & 12 & 3.28 \\
\hline 02 & V1/N3 (F2) & 1.4843 & 12 & 3.28 \\
\hline 03 & V1/N4 (F3) & 2.0723 & 12 & 3.28 \\
\hline
\end{tabular}

DECISION: Calculated F-value for degrees of freedom $\mathrm{dF}_{1}, \mathrm{dF}_{2}$ and $\mathrm{dF}_{3}=12$ is less than the tabulated $F$ value, the null hypothesis is accepted for the $F$ cal. $\left(F_{1}\right)$, $\left(F_{2}\right)$ and $\left(F_{3}\right)$ at 0.05 level 
as (a), (b), (c) and (d). The percent maximum respondents of each category were used for the possible inferences about the opinions and alternative solutions for the suggestions in the curriculum aspects of pharmacy undergraduate program to enhance employability and marketability.

\section{Professional involvement of respondent}

Out of 78 respondents participated in the present curriculum survey, $30.77 \%, 50 \%, 16.67 \%$ and $2.56 \%$ were PIP,PAP,AIOP and CP respectively.

\section{Perception of Pharmacy curriculum}

The consensus of industrial, academic and other than pharmacy professionals was that "pharmacy curriculum needs to be changed partially" as evidenced from maximum preferences of $50 \%$ (PIP), $55.26 \%$ (PAP) and $30.77 \%$ (AIOP) from the total number of responding samples.

\section{Affiliation of pharmacy undergraduate program}

The maximum preferences given by three categories of professional, industrial, academic and other than pharmacy professionals were $33.33 \%, 50 \%$ and $38.46 \%$ for the alphabet code "b" i.e. "Health Science University" out of total number of respective respondents.

\section{Qualification of prospective future pharmacist as} B.Pharm. (Industrial) and B. Pharm. (Clinical)

The maximum percent respondents $45.85 \%$ (PIP) and $44.74 \%$ (PAP) had selected code'd' i.e. "sub branches B.Pharm. (clinical) and B.Pharm. (Industrial) qualification which will provide opportunity to develop their career for right choice of employment and higher studies." Whereas 53.85\% (AIOP) respondents had selected code "b" which indicates that by making two streams, interest and abilities of respective students will be preserved.

\section{Suggestion about the structure of existing pharmacy curriculum}

The maximum percent preferences were given by Industrial professionals $54.17 \%$, for the code ' $a$ ' who demanded extensive revision of curriculum and replacement of modern methodology practiced in the industry. The maximum percent respondents among academic professionals $29.41 \%$, were of the opinion that there should be provision of soft skill development, industrial interactions, assignment and training within the curriculum. $38.46 \%$ AIOPs were of the opinion that there should be uniformity of syllabus at national level similar to AICTE model syllabus.
Area of professional training to pharmacy graduate for employability

The maximum percent industrial professional respondents $54.71 \%$ have suggested area of code "a" i.e. Regulatory and quality management where as $29.41 \%$ of PAPs have suggested the area of New drug delivery system (NDDS) and $53.85 \%$ of AIOPs were of the opinion that these graduates should have adequate training of Modern analytical techniques for job opportunities.

\section{Student awareness about latest pharma Industrial/ clinical development.}

The maximum percent respondents of three categories PAP, PIP and AIOP 41.67\%, 41.67\% and 63.33\% have given their choice as code " $\mathrm{c}$ " which suggested that training needs to be provided to the concerned teaching faculty on technological advancement in the industry.

\section{Induction of soft skill lecture course in the undergraduate degree course in pharmacy.}

The maximum percent respondents of all three categories showed common choice with $45.83 \%, 52.63 \%$ and $30.77 \%$ for code "c" i.e. soft skill lecture course needs to be covered by arrangement of workshop, seminars and guest lectures.

\section{Opinions on services to foster student professionalism}

The PIP with maximum percent respondents 41.67\% have suggested to arrange guest lectures by industrial professionals where as $28.95 \%$ PAP and $38.46 \%$ AIOP were of the opinion to arrange training to teachers on modern teaching methodology and pedagogy.

\section{Teachers to develop job oriented professionalism in the curriculum}

The maximum percent respondents PIP, PAP and AIOP 45.83\%, 31.43\%, 33.3\% have selected code "c" which suggested participation in workshop, seminars on curriculum development and modern teaching methodology.

\section{Specific areas of training for employability in Clinical / Health care industry.}

PIP with maximum percent respondents $52.17 \%$ were of the opinion that clinical industry employment will require adequate training in phase 0 to phase IV clinical trial and GCP guidelines. Whereas PAP and AIOP with maximum percent respondents $34.29 \%$ and $66.67 \%$ suggested monitoring, reporting, maintenance of data and documentation for specific job opportunities. 


\section{Soft Skills required to cultivate professionalism}

PIP and PAP with maximum percent respondents $41.67 \%$ and $50 \%$ preferred behavioural trait such as attitude, motivation and time management where as $63.64 \%$ of AIOP respondents suggested communication skill as a preferred soft skill for the cultivation of professionalism.

\section{Type of training required for job opportunities in clinical industry}

PIP and PAP with maximum percent respondents $54.17 \%, 31.43 \%$ have selected areas of clinical trial data collection and management whereas 36.36\% AIOP have selected NDD for training.

\section{$R$ and $D$ area in which pharmacy graduate get acquainted with for employability}

The maximum percent PIP respondents 56.52\% have preferred area of development methods of NCE, NDA and ANDA. The PAP respondents $32.35 \%$ have preferred analytical methods for scale up technique whereas $36.36 \%$ AIOP respondents have preferred calibration and maintenance of lab instrument and GMP.

\section{Evaluation method of good pharmacy education practice}

All three categories of respondents PIP, PAP and AIOP with maximum percent respondents $52.18 \%, 44.12 \%$ and $58.33 \%$ have preferred objective test after guest lecture/seminar/workshop to evaluate the performance and relevant changes for the improvements.

\section{DISCUSSION}

Questionnaire survey design was used to generate opinions of four types of professionals connected directly or indirectly to the pharmaceutical education. Industrial Pharmacy professionals, Academic pharmaceutical professionals, Professionals working in pharmacy industry other than pharmacy and Clinical pharmacy professionals. Sampling methods for questionnaire survey in human subjects were direct face to face, and indirect by electronic mail w.w.w. surveys. In the sampling by questionnaire, the results may bias as non-respondent by electronic mail were more than the respondent. Since subjects were randomly assigned to solve the questionnaire, preferences in each group were independent from those of other group.

The data reflected completely randomized design. The F-statistic test of randomized analysis of variance was employed to analyse the data which include human subject's academic, industrial, industrial professional other than the pharmacy and clinical professionals.
The implementation of data of three professionals was based on the percent maximum respondents to the questions.

Fourth professional from clinical pharmacy profession, was not taken for the analysis as the data from these human subjects was unavailable. It was opined that, pharmacy curriculum needs to be changed partially. The under graduate pharmacy program to be affiliated to the Health Science University. As pools of students opt for pharmacy undergraduate course is compromised between engineering and medical profession, student usually takes up pharmacy education as a career because of extensive opportunities as a blend of pure and applied professional sciences which include both medical and engineering. As a qualified pharmacist, job opportunities in industry are extensive in comparison with the job opportunities in health care program. Recently there is an acute shortage of the candidates with specialization in the areas of clinical and pharmacological sciences as students get easily accommodated in the industrial specialization, against vacancies for higher education. It is suggestive to develop pharmacist during undergraduate course work based on their innate abilities, attitude and performance towards the pharmacy professional education, to select the subjects based on their choice, which can offer them qualification B.Pharm. (Pharmaceutical Industry) or B.Pharm. (Clinical Industry). B.Pharm. (Pharmaceutical Industry) would choose pharmaceutical industry oriented job and post graduate academic program in pharmaceutical industry related subjects. Whereas B.Pharm. (Clinical Industry), would choose biological product development jobs, clinical research, post graduate academic programs in biopharmaceutics, pharmacy practice, and pharmacology or Pharm. D. post-baccalaureate curriculum to practice pharmacy profession.

\section{CONCLUSION}

It is emphasized by the industrial professionals to make the provision to train concerned teaching staff by participation in teachers training course, to provide adequate training to the prospective candidates for industrial jobs in the areas such as regulatory and quality management, modern analytic techniques, clinical research and novel drug delivery system. For job employability, pharmacy graduate should be aware of the latest pharmaceutical or clinical industrial developments. This knowledge of development may be either by attending guest lecturers delivered by pharmaceutical or clinical experts. Workshops or seminars can organized on recent developments on new drug delivery, manufacturing process etc 
or by signing, MOU for collaborative interactions with sponsored research work at college level and to encourage research students to assist research work at industrial level.

\section{ACKNOWLEDGEMENT}

Authors wish to express gratitude and support from Dr D.M. Ingawale, President, S\&KVPM's Sahyadri College of Pharmacy, Methwade during M.B.A. (II) research project MBA distance education, Shivaji University, Kolhapur 2014-2015.The present research work is presented in the poster session in $20^{\text {th }}$ APTICON, 9-11 Oct.2015 held at Indore, M.P., India.

\section{CONFLICT OF INTEREST}

Authors declared that there is no conflict of interest in this research project work.

\section{ABBREVIATION USED}

NDA: New Drug Application; GCP: Good Clinical Practice; BA/BE: Bioavailability/Bioequivalence; PMS: Post Marketing Surveillance; CR: Clinical
Research; ICF: Informed consent form; NCE: New Chemical Entity; ANDA: Abbreviated New Drug Application; GMP: Good Manufacturing Practice; NDD: New Drug Delivery.

\section{REFERENCES}

1. NCVER: Employability, skills for the future. VOCED Plus International tertiary education research database 2002; Department of Education, Science and Training, Canberra. Available from: http://hdl.voced.edu.au/10707/62282. pp1-74. (Last accessed on 2016 Sept02).

2. Brown P, Hesketh AJ, William S. The mismanagement of Talent : Employability and jobs in the knowledge based economy. University Press Scholarship Talent online. 2004.Oct.2011. Available from: http://www.oxfordsholarship. com/view/10.1093. (Last accessed on 01.09.2016).

3. Guvinder K, Sharan K. M alaysian Graduates Employability skills Unitar E-Journal. 2008; 4: 14-44.

4. Pande VV, Shastri KV, Tekade AR, Tanker AN. Career orientation program for 1st year degree pharmacy students: facilitating personal effectiveness leader effectiveness and resource effectiveness. Internl J Pharm Tech Research. 2009;1:313-6.

5. Sood M : The national graduate employability blue print 2012-2017. Ministry of Higher Education 2012. Available from http:www.scribd.com. (last accessed on 01.09.2016).

6. Arshad SR, Wahindin IS. The development of Malaysian online employability test kit.

7. Desale P. An overview about pharmacy education in India. India J Res Pharm Biotechnology. 2013;1(3):329-32.

\section{SUMMARY}

- Questionnaire survey design was generated using fifteen multiple choice questions from 78 human subjects comprising of four groups, academic, industry, clinical and academic/industry other than pharmacy professionals.

- Sampling was performed directly by face to face by circulating questionnaire survey sheet or indirectly via electronic mail service. Samples were tabulated category wise and preferences and analyzed by F-statistic test. The data was interpreted based on the percent maximal preferences given by each category of respondents and used to draw inferences about opinions and alternative solutions in the undergraduate curriculum of degree pharmacy.

- It is emphasized to develop qualified pharmacist, during undergraduate course work, based on their abilities, attitude and performance towards pharmacy profession, to provide adequate training for industrial job in the areas of regulatory and quality management, modern analytical technique, clinical research and novel drug delivery system.

\section{About Authors}

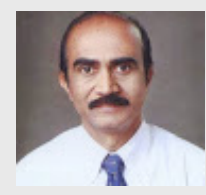

Prof, Shivaji Prataprao Gawade: Is borned in 1952. Presently he is a Professor at Sahyadri College of Pharmacy, Methwade, Tal. Sangola, Dist Solapur -413307, M.S., India. He is graduated from Dept. of Pharmacy, College of Engg., Karad, Shivaji University, Kolhapur in 1974 , M.Pharm (1977) and Ph.D. (faculty of Technology) (1981) from Haffkine Institute, Parel,,Bombay University and M.B.A. (Executive) Distance Education from Centre of Distance Education, Shivaji University, Kolhapur, 2016. His areas of research include Pharmacology of venoms \& toxins, Neuromuscular Electrophysiology, Neuro-psychopharmacology, Pharmaco-photodynamics.

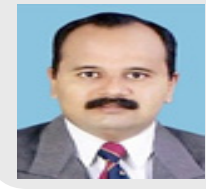

Capt.(Dr) Nitin P.Sonaje ME, PhD (Civil Engg), MBA, MIE, MIME: Presently working as a Deputy Registrar ,Shivaji University, Kolhapur. He was Former Registrar, Solapur University and Former Director, Center for Distance Education, Shivaji University, Kolhapur. He had served in Indian Army (Corps of Engineers) as a Short Service Commissioned Officer.

Cite this article: Gawade SP, Sonaje NP. Designing of Curriculum Aspects of Pharmacy Undergraduate Course in Respect of Graduate Employability. Indian J of Pharmaceutical Education and Research. 2017;51(4):502-9. 